\title{
Questão Pública: \\ First Voting Advice Application in Latin America
}

\author{
Alejandra Marzuca ${ }^{1}$, Uwe Serdült ${ }^{2}$, and Yanina Welp ${ }^{2}$ \\ ${ }^{1}$ Universidad Católica del Uruguay, Montevideo, Uruguay \\ amarzuca@ucu.edu.uy \\ ${ }^{2}$ Centre for Democracy Studies Aarau, Switzerland \\ \{uwe.serdult, yanina.welp\} @zda.uzh.ch
}

\begin{abstract}
Questão Pública was a Voting Advice Application website set up for the 2010 Senate elections in Brazil. Promoted by a consortium of Brazilian and international NGOs as well as universities, Questão Pública was not only a research but also a political initiative. The consortium understood Questão Pública as a complementary tool to reinforce transparency and accountability during an election campaign. The paper presents a description of this experience, of candidate and user response resps wellas a discussion of the main features of the Voting Advice Application. We furthermore report on technical aspects, the questionnaire, and the diffusion activities the consortium undertook to convince candidates to participate as well as to attract users.
\end{abstract}

Keywords: Voting Advice Application, election, online survey, Brazil.

\section{Introduction}

A Voting Advice Application (VAA) is defined as a non-partisan online device assisting voters to find out more about the candidates and political parties running for office in an election. A VAA attempts to achieve this goal by offering the Internet user systematic information about the policy preferences of political parties or candidates. The Internet user typically has to respond to a questionnaire touching upon select political issues with the parties or candidates having positioned themselves beforehand. As a result, the VAA produces a match between the political positions of the potential voter (in our paper the VAA user, or simply the user) and a party or a candidate [1]. The VAA usually represents this match in the form of a chart or a table (oftentimes based on a percentage) illustrating how far away the user is from the political parties or candidates. Electoral offer and demand are thus compared and graphically displayed on a website for each individual user.

Since the first experience with a VAA (1998 in the Netherlands), the number of constituencies with VAA platforms during election time as well as the number of VAA users have considerably increased ${ }^{1}$. VAAs became quite common in Europe and

${ }^{1}$ See [1] for examples. The Swiss VAA 'smartvote' increased the number of voting advices from $255^{\prime} 000$ in 2003 to almost one million in 2007, whereas in Germany the Wahl-O-Mat (www.wahl-o-mat.de) started with 3.6 million voting advices in the 2002 elections, and delivered over 6.7 million voting advices during the campaign of the 2009 elections [3]. 
the United States over the last decade [2], [3]. Until recently, however, this democratic innovation had not made it to Latin America. Questão Pública (QP) contained the first VAA implemented on this continent ${ }^{2}$. Promoted by a consortium of Brazilian and international NGOs together with universities ${ }^{3}$, QP aimed at being a complementary tool helping to reinforce transparency, to promote civic education and to increase accountability on the occasion of the Brazilian Senate elections of 3 October 2010.

Out of a total of 272 eligible candidates for the Senate elections in all 27 Brazilian states, 58 candidates in 16 states completed the QP questionnaire. The VAA was consulted about 8'000 times. In the following pages we describe and analyze this Brazilian VAA experience in 2010. The article starts off with a brief review of the discussion on VAA research so far, followed by a description of QP, then addresses project implementation and results, and finishes by drawing up conclusions and providing avenues for future research.

\section{Why Using a VAA?}

VAAs have become a well-known tool during election campaigns in most European countries. One of the strongest arguments in favor of them is the fact that, by requiring parties and candidates to openly declare their positions on a series of policy issues, they can help to situate the public discussions during the campaign. Furthermore, VAAs try to raise awareness for (perhaps neglected) political issues and offer guidance related to party preferences, taking into account topics of the current political debate [2]. In most cases VAAs are advertised as reliable tools capable of aiding voters to make informed decisions, enhancing and strengthening fundamental democratic principles such as transparency and accountability [3], but also as a means to have a positive effect on voter turnout. More recently, researchers are trying to use VAA generated data to analyze the positioning of political parties in an ideological space [4].

According to Fivaz et al. [3] a 'first wave' of publications on VAAs has focused more on the description of VAAs and their features, whereas a second wave, larger in respect to the number of published studies, is attempting a more in-depth approach by focusing on empirical studies and by developing a more critical stance towards the object under study [14]. The spread of VAAs in the last decade has created a new field of research in which contextual factors such as the features of the political system or the role played by the media are taken into account for the analysis [5].

In the case of the very popular Swiss version, called smartvote, Nadig and Fivaz [6] explain that its growing popularity among the candidates can be attributed, to a certain extent, to the "marketing" instruments deployed to promote the website (e. g. candidate profile with smartspider and smartmap visualizations), which is also linked

\footnotetext{
${ }^{2}$ Since Spring 2010 the e-Democracy Centre (www.edemocracycentre.ch) started to cover selected elections with their own VAA (see research section for a full list).

3 ABRACCI, Avina Foundation, Ethos Foundation, Agora Institute, Center for Research on Direct Democracy (c2d), Transparency International and Gov2u were members of the consortium (http://www.questaopublica.org.br/).
} 
to the rise of the Internet in general. The mass media show a high interest in these candidate profiles and frequently print them - often in an attempt to compare candidates. For Garzia [7] the main reason for the success of the ideas behind VAAs lies in the increasing number of swing and undecided voters who need help in making up their mind. Accordingly, cross national analysis stresses that these tools are more popular in highly fragmented political systems and/or complex electoral systems where casting an informed vote is more time consuming. In some cases it was found that such tools encouraged voters to acquire more information on politics and political parties, positively affected turnout and even affected their vote intentions [7]. For other authors there is only little evidence supporting a positive relation between the use of VAAs and voter turnout [8].

Questão Pública was the first VAA implemented in an emergent and at the same time very large country such as Brazil (with 191 million inhabitants) combining a considerable digital divide with a growing Internet diffusion and online activism in civil society [9]. According to data from the International Telecommunication Union [10] $39.2 \%$ of the Brazilians are Internet users, positioning the country as one of the leaders in the region. Furthermore, several studies have shown the active use of online social networking sites ${ }^{4}$. However, only middle and upper classes have taken advantage of this development. Most Internet users are young, have a high level of education and live in urbanized areas.

On the political side, Brazil has a strong presidential system and a highly fragmented party system since the transition to democracy, with a large number of political parties forming coalitions in order to be able to access political power. Political parties are weak but individual political leaders are strong [11]. This is the context in which candidates interact with a VAA. However, QP was not only a research initiative but also a campaign by political activists.

\section{Questão Publica, the Brazilian VAA}

\subsection{The Senate}

With 191 million inhabitants, Brazil is a federal presidential republic of the federal government, states and municipalities. The president is both head of state and chief of the executive branch of the federal government. The legislative power is vested in the Chamber of Deputies and the Federal Senate, and these two houses make up the National Congress. According to Desposato [12] the Senate is the more powerful of the two institutions, given that it has the sole authority to set total debt limits for all levels of the Brazilian government and to decide on international financing. The Senate has the exclusive power to impeach and try the president, ministers, Supreme

4 Brazilian consumers spend an average of 19.3 hours online for personal use versus 9.8 hours watching TV, according to a study released by Deloitte.

See: http://venturebeat.com/2009/06/22/brazil-social-advertisings-next-frontier/ (accessed in September 2010). Another study by the social media company Sysomos Inc shows that Brazil is the fifth-largest nation of Twitter users.

See: http://latamthought.org/2009/07/13/twitter-in-brazil/ (accessed in September 2010). 
Court justices, and other authorities. The Senate also approves many key appointments and chooses many federal judges.

Each one of the 26 federal units as well as the Federal District elects three senators (total of 81), for an eight-year term. In one election (every four years) one third (27) of the senators are elected and in the following one the other two thirds (54). The Senate is selected via single and multi-member plurality elections and is headed by the Board of Directors ${ }^{5}$, elected by the members of the Parliament every two years.

Brazil has a multi-party system, highly fragmented since 1985 , with a large number of political parties forming coalitions in order to access political power. Since 1990 not fewer than eighteen parties were represented in the Chamber of Deputies, and none of them gained a quarter of the seats ${ }^{6}$. Finally, though political parties are weak, in the states the political leaders are strong. An incumbent senator can simply switch political parties and take with him most of his supporters. Furthermore, candidate nominations are quite often declared by the senators themselves.

The consortium also decided to implement the VAA for the senatorial elections in order to counter the mass media focus on the presidential elections. A number of organizations aiming to reinforce democracy see the platform as a complementary tool to turn around the growing lack of confidence that citizens have in the Parliament, bolstered by frequent corruption scandals. Many citizens do not know who their representatives are and what they stand for. The focus on the Senate was seen as a way to reinforce the institution and its role, to provide information about candidates and to center the campaign on ideological issues. Asking candidates to position themselves during the campaign was seen as a way to reinforce the role of ideology in an election and to promote control and accountability beyond elections (positioning as the basis to exercise control after the elections).

\subsection{Project Design}

Three important decisions have to be taken in order to implement a VAA. These are the design of the questionnaire, the options to collect candidates' positions and more technical aspects such as the algorithm applied to compare users' preferences with those of the political parties or candidates.

a) The questionnaire: The main challenge for the design of a VAA questionnaire is to identify the most relevant issues on the political agenda, to establish a balance between different ideological positions, and to avoid ambiguous phrases.

Therefore, the language used should be simple and widely understandable, especially when the target is the entire electorate. The questionnaire composed of 35 issue statements was elaborated by specialists, discussed by the network of the NGOs and tested with different social groups before being uploaded. As it is a political activism initiative, tension occurred between the NGOs and partners with a more

\footnotetext{
5 The Board is composed of the President, two vice-presidents, four secretaries and four deputy secretaries.

${ }^{6}$ Coalitions are usually headed by the four major parties: the Workers' Party (PT), the Brazilian Democratic Movement Party (PMDB), the Brazilian Social Democracy Party (PSDB) and the Democrats (DEM). Sorted according to their ideological position from left to right: PT (leftcentre), PSDB (centre-left centre) PMDB (centre) DEM (right centre) [13].
} 
academic profile with regard to the definition of some questions, which were considered to be crucial for some, but biased for others. Here is a sample of statements (for the complete list in Portuguese, see Annex 1):

1. The age of criminal responsibility should be reduced to 16 years

2. Brazil should stimulate the transformation of MERCOSUR into a supranational institution such as the European Union

3. The fuel tax should be increased to subsidize public transport

4. Public universities should charge a monthly fee to those who can pay

5. Religious education must be part of the public school curriculum

6. Abortion in early stages of pregnancy should be legalized

The questionnaire provided a five-point response scale allowing one to express strong or moderate positions of agreement and disagreement. The categories were: absolutely agree, agree, neither agree nor disagree, disagree, absolutely disagree, and not interested. The crucial question regarding answer categories is whether you allow the user, the candidates, or both to be neutral towards an issue statement, or even not to answer at all. All those choices linked with the set up of a VAA have consequences of how the applied matching algorithm performs - in the end deciding on the validity of the whole exercise.

b) Positioning: The answers of candidates or political parties can be provided via the assessment of non-partisan experts, the political parties themselves or via an individual response of candidates. In the QP experience the last option was the only one considered, given the overall focus of the project on political activism. In that sense, QP sought to have an effect not only on the voters but also on the candidates and on the future senators who should expect to be controlled by the NGOs in the fulfillment of their promises.

A problem to be considered when a VAA is applied on this basis is timing. Given that the list of official candidates was provided at the end July, although legal procedures continued until the election, there was a delay in starting the campaign to get candidates' answers. Then, the novelty of the initiative meant that several discussions had to be conducted with most of the candidates until some of them decided to provide answers to the questionnaire. In a huge country such as Brazil, the consortium was able to focus only on some regions. Initially, these regions were the ones with more Internet access, despite the fact that a few candidates from places with very low Internet spread joined (e.g. Amazonas), while in areas with a higher Internet diffusion such as São Paolo QP did not reach a very high response rate. This produced a second problem, which is that the electoral campaign was developed in a short period but QP needed candidate answers in order to work as such and to be meaningful for the users. The fact that there were not enough answers resulted in a delay of the launching, decreasing the opportunity for a greater impact. Some lessons should therefore be learned for future experiences ${ }^{7}$.

c) Linking preferences, procedural and output options: Setting up a VAA involves a couple of procedural and methodological decisions. In a nutshell, we can observe

${ }^{7}$ A more detailed project report can be found at www.dd-la.ch (4th ZDA-AVINA Report, November 2010). 
from our recent VAA experiments around the globe that every single parameter of a VAA can have an effect on the result, usually being a matching coefficient or a percent match value between the candidate's and the user's political preferences. Even factors we cannot control such as the number of candidates and the perception of what a good match actually is in the eyes of the users (distance vs. directional voters) will influence the validity of the whole exercise.

For a VAA the quality of the questions asked is crucial. First of all, the catalog of questions has to cover the political spectrum of all the political parties or candidates otherwise the result will be biased. In our view it is best to test the questions beforehand with a representative survey as Walgrave et al. suggest [14]. For each question we could then test how they perform for they are supposed to divide candidates and users into distinct political camps in order to work out the ideological differences between them. We therefore prefer questions producing an M-shaped frequency distribution with more answers on each side of the argument and fewer in the middle (on a five point scale with a neutral category in the middle). However, and probably quite typical for the ordinary VAA providers, such a time consuming and costly procedure was not an option for the QP project. The questionnaire was thus developed with the help of secondary data and literature [13], generating the already mentioned debate between political activists and academics. It goes without saying that one and the same question can perform very well in one electoral system and context but not in the other.

Question specific traits such as the scale, whether to allow a middle category, whether to allow candidates to refuse answering a question or not, simply the number of questions asked are all factors influencing the quality of a VAA. Some VAAs also allow their users to attach more or less weight to certain questions or thematic sections of questions.

Last but not least, there is a myriad of matching algorithms available. Depending on the context of the election either Euclidian distance models, scalar products, matrix models or rank-order coefficients perform better. Based on our VAA experiments we opted for a Euclidian distance model which seemed to produce stable results.

\subsection{Outcomes}

In October 2010, the Brazilian Senate was about to renew two thirds of the seats, out of a total of 81 . Those seats were contested by 272 candidates in 27 districts. Despite the intense campaign to contact all candidates, and the strong influence reputation of some of these NGOs (such as ABRACCI), only 58 candidates from 16 states answered the questionnaire. The VAA was consulted by roughly 8'000 Brazilian citizens. 6'360 of them reported their socio-demographic data after completing the questionnaire. ${ }^{8}$

${ }^{8}$ The data set for the socio-demographic questions was generated from the MySQL database of the VAA via a csv-file. Original treatment was done with the help of Notepad++. The data was then read into PASW Statistics 18.0.1 (better known as SPSS). The data set consists of 6'360 entries and the following variables: ID, IP-ID (anonymous), State, Duration, Date, Gender, Year of birth, Education, Vote intention (Presidential), and User location. You can obtain it via Email from the authors or find it on www.dd-la.ch . 
Table 1 shows the total candidates by state, and the candidates who responded $(\mathrm{CwR})$; the number of users by state $\left(n=6{ }^{\prime} 360\right)$ and the percentage over the total users. A first finding that emerges is that there is no correlation between the size of the district in terms of voters, the number of seats contested or the number of candidates and a bigger or smaller rate of answers. Although the users came mostly from São Paolo (66.7\%), only $33 \%$ of the candidates answered the questionnaire (5 of 15). Whereas in Rio Grande do Sul $78 \%$ of the candidates answered the questionnaire (7 of 9$)$ but there were only 147 VAA users declaring to live in that state $(2.3 \%$ of the total users).

Table 1. QP, candidates and candidates positioning, user and percentage over the total users

\begin{tabular}{lccccc}
\hline States & Candidates & CwR & CwR \% & Users & Users \% \\
\hline São Paolo & 15 & 5 & 33 & 4242 & 66.7 \\
Rio do Janeiro & 11 & 7 & 64 & 519 & 8.2 \\
Minas Gerais & 10 & 4 & 40 & 499 & 7.8 \\
Paraná & 7 & 5 & 71 & 248 & 3.9 \\
Santa Catarina & 11 & 5 & 45 & 211 & 3.3 \\
Rio Grande do Sul & 9 & 7 & 78 & 147 & 2.3 \\
Bahia & 10 & 4 & 40 & 120 & 1.9 \\
Amazonas & 8 & 2 & 25 & 109 & 1.7 \\
Goiás & 8 & 5 & 62 & 71 & 1.1 \\
Ceará & 10 & 3 & 30 & 51 & 0.8 \\
Alagoas & 10 & 2 & 20 & 46 & 0.7 \\
Maranhão & 11 & 2 & 18 & 28 & 0.5 \\
Acre & 4 & 2 & 50 & 23 & 0.4 \\
Rondônia & 7 & 2 & 28 & 18 & 0.3 \\
Sergipe & 14 & 1 & 7 & 19 & 0.3 \\
Piauí & 12 & 2 & 17 & 9 & 0.1 \\
Total & 157 & 58 & -- & 6360 & 100 \\
\hline
\end{tabular}

Regarding gender, we can further report that there is a dominance of men among the total number of candidates $(86.8 \%)$, the candidates who responded $(84,5 \%)$ and the elected candidates $(85 \%)$. The same applies for the educational level, whereby the ones with a higher level of education dominate among the number of candidates $(82.4 \%)$ and candidates who responded $(87.9 \%)$. The same applies to age. There are no major differences between the total number of candidates and respondents. In both cases most of them are located within the age-group 45 to 59 (representing $55 \%$ of he total candidates and $55 \%$ of the candidates who responded), followed by the groups before and after, that is, 35 to 44 (representing $18.7 \%$ of the total candidates and $17.2 \%$ of the candidates who responded) and 60 to 69 (representing $18 \%$ of the total candidates and $17.2 \%$ of the candidates who responded).

The previous suggests that the profile of candidates who joined QP fits with the general profile of candidates who were running for the Senate in terms of gender, age and educational level.

How can the small number of candidates' answers be explained? Although further research should be done, it is possible to suggest some hypotheses. Although the campaign is the place to share and discuss ideas, taking public positions on issues 
such as abortion tends to be a risk for a 'catch-all' party candidate. In a highly fragmented political system, strong candidates such as incumbents from major parties have fewer incentives to include innovations in their campaign strategy (such us joining a VAA), given their dominant or powerful position in the political arena. In contrast, weaker candidates (from small or new political parties) have a much higher incentive to innovate in order to increase their influence or their presence in the mass media, which is normally dominated by leaders of the bigger political parties. Given that QP was used for the first time, the application had to win a space in the media (mass and social media). Other experiences (e.g. smartvote in Switzerland) have shown that, as soon as a VAA gains in importance, a certain pressure to join can build up on the candidates [15].

The expected link between small parties and a bigger incentive to join an innovative campaign tool such as a VAA can be confirmed. Although some candidates of parties that gained more seats in the Senate created their public profile on the QP website (eg. 23 candidates were from PMDB, which won 16 seats, while 5 candidates answered the QP), we found that there was a greater participation of candidates from parties that won only a few seats (PSOL, PV, PPS, DEM) or none at all (PCB, PSTU). For example, PSO presented 39 candidates, 8 answered the questionnaire and only 2 were elected. PCB presented 21 candidates, 8 answered the questionnaire but none of them got elected. Table 2 also shows that, among the 58 candidates who responded, only four won seats (PMDB, PT, PSDB and DEM won $16,11,5$ and 2 seats, respectively).

Table 2. Elected senators, candidates and candidates who responded $(\mathrm{CwR})$ by party

\begin{tabular}{lcccccc}
\hline Political Parties & \multicolumn{3}{c}{$\begin{array}{c}\text { Elected } \\
\text { senators }\end{array}$} & Candidates & CwR \\
\cline { 2 - 7 } & $\mathrm{N}^{\mathbf{0}}$ & $\%$ & $\mathrm{~N}^{\mathbf{o}}$ & $\%$ & $\mathrm{~N}^{\mathbf{o}}$ & $\%$ \\
\hline Party Socialism and Liberty (PSOL) & $\mathbf{2}$ & $\mathbf{3 , 7}$ & $\mathbf{3 9}$ & $\mathbf{1 4 , 3}$ & $\mathbf{8}$ & $\mathbf{1 3 , 8}$ \\
Brazilian Communist Party (PCB) & $\mathbf{0}$ & $\mathbf{0}$ & $\mathbf{2 1}$ & $\mathbf{7 , 7}$ & $\mathbf{8}$ & $\mathbf{1 3 , 8}$ \\
Socialist Party of Workers' Unified (PSTU) & $\mathbf{0}$ & $\mathbf{0}$ & $\mathbf{2 6}$ & $\mathbf{9 , 5}$ & $\mathbf{8}$ & $\mathbf{1 3 , 8}$ \\
Brazilian Democratic Movement Party (PMDB) & $\mathbf{1 6}$ & $\mathbf{2 9 , 6}$ & $\mathbf{2 3}$ & $\mathbf{8 , 5}$ & $\mathbf{5}$ & $\mathbf{8 , 6}$ \\
Green Party (PV) & $\mathbf{0}$ & $\mathbf{0}$ & $\mathbf{1 6}$ & $\mathbf{5 , 9}$ & $\mathbf{5}$ & $\mathbf{8 , 6}$ \\
Socialist Peoples' Party (PPS) & $\mathbf{1}$ & $\mathbf{1 , 8}$ & $\mathbf{7}$ & $\mathbf{2 , 6}$ & $\mathbf{5}$ & $\mathbf{8 , 6}$ \\
Democrats (DEM) & 2 & 3,7 & 12 & 4,4 & 4 & 6,9 \\
Progressist Party (PP) & 4 & 7,4 & 13 & 4,8 & 3 & 5,2 \\
Labour Party of Brazil (PT do B) & 0 & 0 & 3 & 1,1 & 3 & 5,2 \\
Workers' Party (PT) & 11 & 20,4 & 22 & 8,1 & 2 & 3,45 \\
Christian Labour Party (PTC) & 0 & 0 & 2 & 0,7 & 2 & 3,45 \\
Brazilian Labour Party (PTB) & 1 & 1,8 & 6 & 2,2 & 1 & 1,7 \\
Brazilian Social Democracy (PSDB) & 5 & 9,2 & 17 & 6,3 & 1 & 1,7 \\
Brazilian Labour Renewal Party (PRTB & 0 & 0 & 7 & 2,6 & 1 & 1,7 \\
Communist Party of Brazil (PC do B) & 1 & 1,8 & 10 & 3,7 & 1 & 1,7 \\
Party of National Mobilization (PMN) & 1 & 1,8 & 3 & 1,1 & 1 & 1,7 \\
Brazilian Republican Party (PRB) & 1 & 1,8 & 3 & 1,1 & 0 & 0 \\
Republic Party (PR) & 3 & 5,5 & 5 & 1,8 & 0 & 0 \\
Christian Social Party (PSC) & 1 & 1,8 & 4 & 1,5 & 0 & 0 \\
Socialist Brazilian Party (PSB) & 3 & 5,5 & 8 & 2,9 & 0 & 0 \\
Democratic Labour Party (PDT) & 2 & 3,7 & 6 & 2,2 & 0 & 0 \\
Others* & 0 & 0 & 19 & 7 & 0 & 0 \\
Total & 54 & 100 & 272 & 100 & 58 & 100 \\
\hline
\end{tabular}

* Others: parties did not win seats or candidates did not respond: PCO; PHS; PSDC;PSL; PTN 
On the side of the citizens, starting from the point in time when the VAA was activated, the QP website received a total of about 20,000 visitors (not visits) according to Google Analytics, most of them concentrated in the ten days before the election. The peak was reached 2 October 2010 with 3'600 visitors.

The majority of the users answered the questionnaire from home (68\%), followed by those who responded from the workplace $(26 \%)$, while the other options (academic center, public access centers, houses of other people) were chosen by $2 \%$ or less $\left(\mathrm{n}=6{ }^{\prime} 109\right)$.

Analyzing users by age $(n=6 ' 214)$, it is possible to observe that the greatest number of responses came from the group of 21 to 30 years old $(38 \%)$, followed by the group 31 to 40 years old $(20 \%)$. The same data, disaggregated by gender $(n=6220)$, shows the existence of a gap, which is reinforced in older age groups. $60 \%$ of the total users were men and $40 \%$ women. However, the average gender difference of 20 percent goes down to a 3 percent difference within the group of the youngest users with an age of under 20 years.

What the previous data suggests is that the profile of citizens who used QP is related to the features adopted by the digital divide, which includes more young, males, and people with an Internet connection at home.

\section{Conclusions}

Although VAAs are now well-known and accepted in Europe and the United States since more than a decade, QP was the first experience in Latin America promoted by a consortium of local and international NGOs together with universities. It was focused on the Senate with the intention to reinforce the role of an institution characterized by the lack of confidence and clientelistic practices. Important goals of $\mathrm{QP}$ were to provide information, to promote a politically neutral campaign and to create the basis for more democratic control and transparency.

Candidates had to position themselves. Despite the campaign developed by the consortium only 58 out of 272 candidates responded. A curious finding comes from the fact that although the promoters in São Paolo developed a stronger campaign, and most of the users were concentrated in that state $(66 \%)$, only $33 \%$ of candidates answered the questionnaire, much less than the $64 \%$ in Rio de Janeiro, $71 \%$ in Paraná or $78 \%$ in Rio Grande do Sul.

At the same time, a good proportion of the answers came from candidates of small parties. This could be explained by their limited access to mass media and their reduced chances of being elected. In these cases, incentives to join an innovative application are stronger than it is for their counterparts, who have greater chances of being elected and have more incentives to keep their voters uninformed about their detailed political preferences.

Future research should find out to what extent the ideology of political parties plays a role in increasing (or not) the probabilities of a candidate to join a VAA application. As an exploratory hypothesis, it could be suggested that 'catch-all' parties are less inclined to show positions on controversial issues such as abortion or gay marriage. In contrast, small parties could have more incentives to show a clear position trying to increase their public support. 
The profile of users is not surprising, represented more by the young, males, the educated, and people with Internet connections at home. The gender gap is a generational one, with a huge divide between older people and less of a difference found among the young (only 3 percentage points).

For future experiences in the region some recommendations could be considered: contact with candidates is crucial and the response is not obtained immediately; thus, it is essential to develop a solid strategy. It is recommended to expand the networks to communicate with all the parties while reinforcing the contact with main parties, which can produce a 'snowball' effect; mass media should not be underestimated, given that their support could also be crucial for diffusion. Finally, in countries like Brazil, with many initiatives and organizations working for the improvement of democracy, it seems more efficient for everyone to build synergies. In that sense, a VAA could be online on several websites with a common database to collect data, instead of running on one site only.

However, the Internet is spreading and it will reinforce the impact of political initiatives based on VAAs. Despite the low number of users and participating candidates, this VAA has shown the consortium promoting the initiative that a new tool is available for political activism. Future elections will show to what extent the wave of change stimulated by ICTs could generate a change in the political arena.

\section{References}

1. Ramonaité, A.: Voting Advice Applications in Lithuania: Promoting Programmatic Competition or Breeding Populism? Policy \& Internet 2(1), 117-147 (2010)

2. Mayer, C., Wassermair, M.: wahlkabine.at: Promoting an Enlightened Understanding of Politics. In: Cedroni, L., Garzia, D. (eds.) Voting Advice Applications in Europe: The State of the Art. Scriptaweb (2010)

3. Fivaz, J., Pianozola, J., Ladner, A.: More than toys: a first assessment of voting advice applications' impact on the electoral decision of voters. Working Paper 48, NCCR Challenges to Democracy in the 21th Century (2010)

4. Trechsel, A., Mair, P.: When Parties (Also) Position Themselvers: An Introduction to the EU Profiler. Journal of Information Technology \& Politics 8(1), 1-20 (2011)

5. Cedroni, L., Garzia, D.: Voting Advice Applications in Europe: The State of the Art. Scriptaweb (2010)

6. Nadig, G., Fivaz, J.: Internet-based Instruments to Increase Civic Literacy and Voter Turnout. In: ECPR General Conference, Potsdam, Germany (2009)

7. Garzia, D.: The effects of VAAs on Users Voting Behavior: An overview. In: Cedroni, L., Garzia, D. (eds.) Voting Advice Applications in Europe: The State of the Art. Scriptaweb (2010)

8. Fivaz, J., Schwarz, D.: Nailing the Pudding to the Wall: E-Democracy as Catalyst for Transparency and Accountability. In: International Conference on Direct Democracy in Latin America, Buenos Aires (2007)

9. Welp, Y., Wheatley, J.: The uses of Digital Media for Contentious Politics in Latin America. In: Anduiza, E., Jensen, M., Jorba, L. (eds.) Digital Media and Political Engagement Worldwide: A Comparative Study. Cambridge University Press, Cambridge (2012)

10. ITU 2010, http: / /www. itu. int 
11. Nogueira, M.A.: Corrupción en el senado brasileño: síntoma de una crisis de larga duración. Nueva Sociedad 225, 171-188 (2010)

12. Desposato, S.W.: The Impact of Electoral Rules on Legislative Parties: Lessons from the Brazilian Senate and Chamber of Deputies. The Journal of Politics 68(4), 1018-1030 (2006)

13. Power, T.J., Zucco, C.: Estimating Ideology of Brazilian Legislative Parties, 1990-2005: A Research Communication. Latin American Research Review 44(1), 218-246 (2008)

14. Walgrave, S., Nuytemans, M., Pepermans, K.: Voting Aid Applications and the Effect of Statement Selection. West European Politics 32(6), 1161-1180 (2009)

15. Ladner, A, Felder, G., Fivaz, J.: Are Voting Advice Applications (VAAs) more than Toys? First Findings on Impact and Accountability of VAAs. IDHEAP Working Paper 3/2008 (2008)

\section{Annex 1}

1. A carga tributária no Brasil deve ser reduzida

2. Os cidadãos devem participar diretamente das decisões sobre políticas públicas

3. As universidades públicas devem cobrar mensalidades daqueles que podem pagar

4. O desmatamento deve ser totalmente proibido no Brasil

5. O voto no Brasil deve deixar de ser obrigatório

6. Os lucros obtidos com a extração de petróleo devem ser divididos entre todos os estados da federação

7. A adoção de crianças por casais homossexuais deve ser permitida

8. As empresas privadas devem ser proibidas de financiar campanhas eleitorais

9. As invasões de terra são instrumentos legítimos de pressão

10. Um político deve poder indicar pessoas competentes para cargos no setor público, mesmo que sejam seus parentes

11. O governo deve investir em programas sociais para complementação de renda, como o Bolsa-Família

12. Obras culturais financiadas com recursos públicos devem ter livre acesso

13. A maioridade penal deve ser reduzida para 16 anos

14. Para aumentar o número de empregos, direitos como férias, décimo-terceiro e fundo de garantia devem ser flexibilizados

15. Políticos condenados, mesmo em primeira instância, devem ser impedidos de se candidatar

16. Negros devem ter direito a cotas nas universidades públicas

17. O governo deve aumentar o percentual de reciclagem de resíduos sólidos para $50 \%$

18. A anistia geral concedida ao final da ditadura deve ser revista

19. O ensino religioso deve fazer parte do currículo da escola pública

20. As privatizações são benéficas para o país

21. O Brasil deve exercer o papel de mediador em conflitos internacionais

22. A opção pelo aborto deve ser legalizada

23. O imposto sobre combustíveis deve ser aumentado para subsidiar o transporte público

24. Em alguns casos, a violência policial é justificável

25. Mudanças na Constituição devem ser submetidas a referendos e plebiscitos 
26. O Brasil deve estimular a transformação do MERCOSUL em uma instituição supra-nacional, como a União Europeia

27. Se o Brasil precisar de novas termoelétricas, são preferíveis as nucleares às que queimam combustíveis fósseis

28. O número de vezes que um parlamentar pode se reeleger deve ser limitado

29. Oferecer tratamento para viciados em drogas na rede pública legitima o uso

30. A busca da sustentabilidade não deve prejudicar a liberdade do mercado

31. Crimes graves devem ser punidos com pena de morte

32. O Brasil deve aumentar os subsídios econômicos a países vizinhos

33. Políticos e grupos religiosos devem ser impedidos de receber e manter concessões públicas de TV e de rádio

34. A legislação ambiental federal deve levar em conta a particularidade dos biomas e não fronteiras estaduais

35. A qualidade do trabalho dos senadores é de responsabilidade dos eleitores 